\title{
The Examination of Prospective Mathematics Teachers' Perceptions of Lifelong Learning Competencies
}

\author{
Murtaza AYKAÇ *1 (D), Buket ASLANDAĞ ${ }^{2}$ (D), Davut KÖĞCE ${ }^{3}$ (D) \\ ${ }^{1}$ Niğde Omer Halisdemir University, Faculty of Education, Niğde, Turkey, murtazaaykac@gmail.com \\ ${ }^{2}$ Niğde Omer Halisdemir University, Faculty of Education, Niğgde, Turkey, buket.aslandag@gmail.com \\ ${ }^{3}$ Niğde Omer Halisdemir University, Faculty of Education, Niğde, Turkey, kogced@gmail.com \\ * Corresponding Author: murtazaaykac@gmail.com
}

\begin{tabular}{|c|c|}
\hline Article Info & Abstract \\
\hline $\begin{array}{l}\text { Keywords: Lifelong learning, } \\
\text { prospective mathematics teachers', } \\
\text { perception of lifelong learning } \\
\text { DOI: 10.18009/jcer.751476 } \\
\text { Publication Language: English }\end{array}$ & $\begin{array}{l}\text { The purpose of this study is to examine the prospective mathematics } \\
\text { teachers' perceptions of lifelong learning competencies. The study } \\
\text { group of the research consisted of } 1 \text { st, } 2 \text { nd, 3rd and 4th year } \\
\text { prospective teachers studying at mathematics education undergraduate } \\
\text { program of the education faculty of a public university. In this research, } \\
\text { cross-sectional research method was used within the scope of } \\
\text { descriptive research approach in order to reveal how mathematics } \\
\text { teacher candidates' perceptions of lifelong learning competencies have } \\
\text { improved. In the research, as a data collection tool "Key Competencies } \\
\text { for Lifelong Learning" scale developed by Şahin, Akbaşli and Yanpar- } \\
\text { Yelken (2010) was used. Independent samples t-test and one-way } \\
\text { analysis of variance (ANOVA) were used to compare the mean scores } \\
\text { obtained from the scale by variables. The results obtained from the } \\
\text { research indicated that the prospective mathematics teachers } \\
\text { participated in the research have high level of life-long learning } \\
\text { competencies. A significant difference was found in prospective } \\
\text { mathematics teachers' scores of life-long learning competencies as } \\
\text { regards their genders and the high schools they graduate from. } \\
\text { Participants graduated from Anatolian High School and Teacher } \\
\text { Training High School had higher scores than the other participants. } \\
\text { However, no significant difference was found in prospective } \\
\text { mathematics teachers' scores of life-long learning competencies } \\
\text { regarding the year of their study. }\end{array}$ \\
\hline
\end{tabular}
examination of prospective mathematics teachers' perceptions of lifelong learning competencies. Journal of Computer and Education Research, 705-719. DOI: 10.18009/jcer.751476

\section{Introduction}

Today, as a result of the necessity of the information age, the general view of the society in general, and of individuals in particular, regarding information has changed. In today's society, individuals have to constantly improve themselves in order to meet the requirements of the profession, regardless of their profession. Ensuring continuity of education to be given to individuals for this improvement is important for social progress. 
Therefore, lifelong education has gained importance in order for education to reach everyone irrespective of the individual's age and to raise more qualified individuals.

Lifelong education has become a concept considered as a vital target to meet the current needs presented by developing technology in human life, since education provided in schools is insufficient in meeting the needs of individuals in solving their real life problems (Bağc1, 2011). According to Ministry of National Education (MoNE) (2014), lifelong learning is defined as a concept used to describe individuals' learning efforts throughout their lives. Lifelong learning consists of activities and tools that allow individuals to learn more and develop skills. Participation in lifelong learning activities provides personal, social and economic benefits to individuals, families and communities. It offers new knowledge and skills acquisition, better employment opportunities for individuals and personal development opportunities. Thus, it has become necessary to raise individuals who can adapt to changing business, living conditions and technology more rapidly in today's societies. Güleç, Çelik and Demirhan (2012) define lifelong education as a broad concept that covers all formal and non-formal education activities aiming at restructuring the education system and developing all educational potential outside the education system provided in schools. In the "World Bank Report" published in 2003, lifelong learning is defined as a new education-teaching model to meet the demands of individuals in a changing world order, and it is stated that it covers learning within the life cycle from childhood to retirement (The World Bank, 2003). Considering these definitions as a whole, lifelong learning may be regarded as a learning process within the life cycle starting from childhood to retirement to be able to produce solutions to the problems faced by individuals in their real life, to increase their willingness and desire to learn and to improve their entire life skills.

When considered in light of these definitions, lifelong learning should continue at every moment and in all areas of life. This is due to the fact that individuals must be trained to learn on their own and apply their knowledge and skills to their lives in order to fulfill the requirements of the age. In recent years, the rate of access to knowledge, acquisition and change in the content and development of information has led to the loss of validity and usefulness of information for individuals. This, in turn, has given rise to discussions about whether it is sufficient to relay information to new generations only at the level of knowledge (Akbaş \& Özdemir, 2002). In order to achieve lifelong learning goals, teachers should take on a role that teaches ways to access information required by the age instead of 
simply relaying the information. In order for teachers to fulfill this role, they must first be willing and inclined to learn and continue this throughout their professional life (Yaman \& Yazar, 2015).

In today's education system, teachers are expected to guide their students to gain lifelong learning competencies during the education and training process. From this point of view, teachers' ability to fulfill these roles depends only on their undergraduate education at the university before the profession. This is because teachers use their knowledge in their professional lives by creating their own viewpoints regarding education and training based on the education they received during their undergraduate years. In this way, they undertake a pioneering role in shaping the society. In this respect, it is important to find out what the prospective teachers' views towards lifelong learning are. When the studies on lifelong learning with prospective teachers are examined in the literature, it is seen that many studies have been carried out for the purposes of determining the lifelong learning competences of prospective teachers such as lifelong learning competencies of prospective teachers in the study conducted by Gür-Erdoğan (2014), contribution of coding education to the development of lifelong learning competencies of 1st year prospective teachers studying psychological counseling and guidance (PDR) and social studies by Yıldız-Durak and Şahin, (2018), lifelong learning tendencies of 1st and 4th year students and university students studying in different faculties of a university by Coşkun and Demirel (2012), prospective teachers' perceptions of lifelong learning by Demirel and Yağcl (2012), perceptions of 4th year students and prospective teachers studying at a university's education faculty towards lifelong learning competencies by Gencel (2013), perceptions of 4th year students and prospective teachers who are studying in the education faculty of different universities towards lifelong learning by Kılıç (2014), examining the perceptions of all students and prospective teachers studying at a university's education faculty according to various variables by Oral and Writer (2015). Apart from these studies, it can be realized that research has been undergone in the literature on determining perceptions of lifelong learning with other samples other than prospective teachers (Şahin \& Arcagök, 2014; Yaman \& Yazar, 2015). However, within the scope of literature studies, no studies related to lifelong learning perceptions and tendencies of mathematics teachers and prospective teachers have been found. Although studies on other teaching areas and professions have been carried out, considering that mathematics teaching is neglected and mathematics is an important tool 
used in solving many problems encountered in daily life, the lack of research on the perceptions of prospective mathematics teachers towards lifelong learning competencies may be considered as a major deficiency. In addition, the fact that there is no study on how teachers' perceptions of lifelong learning competencies changed during the period from 1st year to 4 th year was an important step in conducting this study. The concept of lifelong learning is a crucial study domain in our country as in many countries. It is hoped that determining the perceptions of prospective mathematics teachers towards lifelong learning competencies will contribute to the field. Thus, the purpose of this study is to examine the prospective mathematics teachers' perceptions of lifelong learning competencies. In order to fulfill this purpose, answers to the following problems were addressed.

1. How do the perceptions of prospective mathematics teachers towards lifelong learning competencies differ by gender?

2. How do the perceptions of prospective mathematics teachers towards lifelong learning competencies change depending on their year of study?

3. How do the perceptions of prospective mathematics teachers towards lifelong learning competencies differ depending on the type of high school they graduate from?

\section{Method}

The sampling group of the research comprisedof 1 st, 2 nd, $3 \mathrm{rd}$ and 4 th year prospective teachers studying at mathematics education undergraduate program of the education faculty of a public university. The investigated statistical population of this study is 239 prospective mathematics teachers who participated in the study willingly and they were chosen via convenient sampling method. Information on the demographic features of prospective teachers taking part in the research is given in the Table 1 below.

Table 1. Demographic features of participants

\begin{tabular}{llll}
\hline Participants' Demographic Features & $\mathrm{f}$ & $\%$ \\
\hline \multirow{2}{*}{ Gender } & Female & 165 & 69 \\
\cline { 2 - 4 } & Male & 74 & 31 \\
\hline \multirow{4}{*}{ Year of Study (Grades) } & 1st Grade & 61 & 25.5 \\
\cline { 2 - 4 } & 2nd Grade & 59 & 24.7 \\
\cline { 2 - 4 } & 3rd Grade & 65 & 27.2 \\
\cline { 2 - 4 } $\begin{array}{l}\text { Type of High School They } \\
\text { Graduate From }\end{array}$ & Anatolian High School & 54 & 22.6 \\
\cline { 2 - 4 } & Anatolian Teacher Training High School & 134 & 56.1 \\
\cline { 2 - 4 } & High School of Science & 37 & 15.5 \\
\cline { 2 - 4 } & Vocational School & 25 & 8.8 \\
\cline { 2 - 4 } & Other (Private School) & 22 & 9.2 \\
\hline Total & & 239 & 100 \\
\hline
\end{tabular}




\section{Data Collection Tools}

As a data collection tool the scale "Key Competencies for Lifelong Learning" developed by Şahin, Akbaşlı and Yanpar-Yelken (2010) was used. The Cronbach alpha reliability coefficient was calculated as 0.88 in the scale development research. Cronbach's Alpha reliability coefficient was determined as 0.77 in the present study. The scale is a kind of 5point Likert type scale consisting of 23 items, including eight sub-dimensions which are as following:

1. Communicative Competence at Native Language,

2. Communicative Competence at a Foreign Language,

3. Mathematical Basis Competence at Science and Technology,

4. Digital Competence,

5. The Competence of Learning to Learn,

6. The Competence of Social Citizenship Awareness,

7. The Competence of the Sense of Initiative and Entrepreneurship,

8. The Competence of Cultural Awareness and Expression.

\section{Data Analysis}

The data collection tool enables participants to expresss their opinions on test items as: absolutely agree: 5 , agree: 4 , undecided: 3 , disagree: 2 , and totally disagree: 1 . The minimum score can be 23 and the maximum score can be 115. The less the score is, the more negativethe attitudes of the participants towards lifelong learning competencies, or vice versa. The analysis of the present study was done by using the statistical program IBM SPSS Statistics 22. In order to determine whether the dataset was modelled for normal distribution, Kolmogorov-Smirnov normality values were used $(.551, .245$, etc). As the skewness and kurtosis values were between +1 and -1 , the dataset was accepted as normally distributed. So as to test the homogeneity of the variences Levene's test results were taken into account $(.462, .861$, etc.). Three parametric statistical procedures, which ran on the data collected by means of the scale, were used in data analysis:

1. Independent-samples t-test was used to find out if there is a difference between the scores of prospective mathematics teachers depending on their genders,

2. One-way analysis of varience (one-way ANOVA) was used to identify the difference of participants depending on their year of study and the high school they graduate from. 


\section{Findings}

In this section, the results obtained by the analysis of the gathered data were given respectively. The minimum and maximum scores, means and standard deviations of prospective mathematics teachers are given below in Table 2 .

Table 2. Minimum and maximum scores, means and standard deviations of prospective mathematics teachers

\begin{tabular}{lccccc}
\hline & $\mathrm{N}$ & $\mathrm{x}$ & $\mathrm{Sd}$ & Min. & Max. \\
\hline Total Score of the Scale & & 86.01 & 19.42 & 23 & 115 \\
\hline 1st Sub-dimension & & 16.94 & 3.76 & 4 & 20 \\
\hline 2nd Sub-dimension & & 11.00 & 4.43 & 3 & 20 \\
\hline 3rd Sub-dimension & & 11.73 & 2.88 & 3 & 15 \\
\hline 4th Sub-dimension & 239 & 7.35 & 1.95 & 2 & 10 \\
\hline 5th Sub-dimension & & 7.96 & 1.89 & 1 & 10 \\
\hline 6th Sub-dimension & & 11.82 & 3.01 & 3 & 15 \\
\hline 7th Sub-dimension & & 15.49 & 3.93 & 4 & 20 \\
\hline 8th Sub-dimension & & 3.69 & 1.11 & 1 & 5 \\
\hline
\end{tabular}

As one can see in Table 2., the minimum score is calculated as 23 and the maximum score is calculated as 115 . The mean of prospective mathematics teachers' scores is 86.01 , which means that prospective mathematics teachers have high levels of the scale "Key Competencies for Lifelong Learning" since their mean is higher than the scale's mid-point. Table 3. indicates the independent samples t-test results as regards to the difference of prospective mathematics teachers' scores and their genders.

Table 3. Independent samples t-test results indicating the gender difference

\begin{tabular}{lccccc}
\hline Gender & $\mathrm{N}$ & $\overline{\mathrm{x}}$ & $\mathrm{Sd}$ & $\mathrm{t}$ & $\mathrm{p}$ \\
\hline Female & 165 & 88.40 & 15.21 & 2.88 & \\
\hline Male & 74 & 80.68 & 25.84 & 2.38 & \\
\hline
\end{tabular}

As regards independent samples t-test results which can be seen in Table 3. a significant difference was observed in participants' scores respected to their gender variables, which is in the favour of female participants. While the mean of female prospective mathematics teachers' scores is 88.40 , the mean of male prospective mathematics teachers' scores is 80.68 . Table 4 . presents the total score variance analysis of total score of participants depending on their year of study. 
Table 4. ANOVA results indicating the difference among prospective mathematics teachers' year of study

\begin{tabular}{lccccc}
\hline Source of Variation & Sum of Squares & Mean Square & $\mathrm{df}$ & $\mathrm{F}$ & $\mathrm{p}$ \\
\hline Between Groups & 187.55 & 62.51 & 3 & & \\
\cline { 1 - 4 } Within Groups & 89580.37 & 381.19 & 235 & .164 & .921 \\
\cline { 1 - 4 } Total & 89767.93 & & 238 & & \\
\hline
\end{tabular}

As shown in Table 4. ANOVA results indicated that no significant difference was found in participants' lifelong learning key competence levels respected to their year of study. Table 5 shows the total score variance analysis of total score of participants depending on the high school they graduate from.

Table 5. ANOVA results indicating the difference among prospective mathematics teachers' scores depending on the high school they graduate from

\begin{tabular}{|c|c|c|c|c|c|}
\hline Source of Variation & Sum of Squares & Mean Square & $\mathrm{df}$ & $\mathrm{F}$ & $p$ \\
\hline Between Groups & 147.98 & 3699.73 & 4 & \multirow{3}{*}{11.548} & \multirow{3}{*}{.000} \\
\hline Within Groups & 74969 & 320.38 & 234 & & \\
\hline Total & 89767.93 & & 238 & & \\
\hline
\end{tabular}

In the analysis of the related data, there was found a significant difference between the total score of prospective mathematics teachers depending on the high school they graduate from $(\mathrm{p}<0.05)$. Means and standard deviations of prospective mathematics teachers'scores are fiven in Table 6 below.

Table 6. Means and standart deviations of participants regarding the high school they graduate from

\begin{tabular}{lccc}
\hline Type of High School & $\mathbf{N}$ & $\overline{\mathbf{x}}$ & $\mathbf{S d}$ \\
\hline Anatolian & 134 & 89.89 & 12.84 \\
\hline Teacher Training & 37 & 92.10 & 11.24 \\
\hline Science & 25 & 71.84 & 26.65 \\
\hline Vocational & 21 & 68.61 & 34.29 \\
\hline Other & 22 & 84.86 & 19.38 \\
\hline Total & 239 & 86.01 & 19.42 \\
\hline
\end{tabular}

As it is seen on Table 6. while the highest mean belongs the participants graduated from teacher training high schools (92.10), the lowest mean score belongs to the participants graduated from vocational schools (68.61). Table 7. indicates the total score variance analysis of sub-dimension scores of participants depending on the high school they graduate from.

Table 7. ANOVA results (with tukey) indicating the difference among prospective mathematics teachers' scores on sub-dimensions of the scale depending on the high school they graduate from

\begin{tabular}{|c|c|c|c|c|c|c|}
\hline $\begin{array}{l}\text { Sub- } \\
\text { Dimension }\end{array}$ & & $\begin{array}{l}\text { Sum of } \\
\text { Squares }\end{array}$ & $\begin{array}{l}\text { Mean } \\
\text { Square }\end{array}$ & $\mathrm{df}$ & $\mathrm{F}$ & $\mathrm{p}$ \\
\hline $1 s t$ & Between Groups & 637.11 & 159.27 & 4 & 13.66 & .000 \\
\hline
\end{tabular}


Aykaç, Aslandă̆ \& Köğce

\begin{tabular}{|c|c|c|c|c|c|c|}
\hline & Within Groups & 2728.28 & 11.65 & 234 & & $(1-3) /(1-4)$ \\
\hline & Total & 3365.39 & & 238 & & $(2-3) /(2-4) /(4-5)$ \\
\hline \multirow{3}{*}{$3^{\text {rd }}$} & Between Groups & 275.01 & 68.75 & 4 & \multirow{3}{*}{9.41} & .000 \\
\hline & Within Groups & 1709.37 & 7.3 & 234 & & $(1-3) /(1-4)$ \\
\hline & Total & 1984.39 & & 238 & & $(2-3) /(2-4)$ \\
\hline \multirow{3}{*}{$4^{\text {th }}$} & Between Groups & 94.21 & 23.55 & 4 & \multirow{3}{*}{6.75} & .000 \\
\hline & Within Groups & 816.26 & 3.48 & 234 & & $(1-3) /(1-4)$ \\
\hline & Total & 910.47 & & 238 & & $(2-3) /(2-4)$ \\
\hline \multirow{3}{*}{$5^{\text {th }}$} & Between Groups & 113.29 & 28.32 & 4 & \multirow{3}{*}{8.91} & .000 \\
\hline & Within Groups & 743.36 & 3.17 & 234 & & $(1-3) /(1-4)$ \\
\hline & Total & 856.66 & & 238 & & $(2-3) /(2-4)$ \\
\hline \multirow{3}{*}{$6^{\text {th }}$} & Between Groups & 297.46 & 74.36 & 4 & \multirow{3}{*}{9.35} & .000 \\
\hline & Within Groups & 1861.15 & 7.95 & 234 & & $(1-3) /(1-4)$ \\
\hline & Total & 2158.61 & & 238 & & $(2-3) /(2-4) /(4-5)$ \\
\hline \multirow{4}{*}{ 7th } & Between Groups & 621.48 & 155.37 & 4 & \multirow{4}{*}{11.87} & .000 \\
\hline & Within Groups & 3062.25 & 13.08 & 234 & & $(1-3) /(1-4)$ \\
\hline & Total & 3683.74 & & 238 & & $(2-3) /(2-4)$ \\
\hline & & & & & & $(4-5) /(5-3)$ \\
\hline \multirow{3}{*}{ 8th } & Between Groups & 35.71 & 8.92 & 4 & \multirow{3}{*}{8.07} & .000 \\
\hline & Within Groups & 258.59 & 1.1 & 234 & & $(1-3) /(1-4)$ \\
\hline & Total & 294.31 & & 238 & & $(2-3) /(2-4) /(4-5)$ \\
\hline
\end{tabular}

As a consequence of the analysis of the related data, there were found significant differences between the scores of prospective mathematics teachers depending on the high school they graduate from in the first, the third, the fourth, the fifth, the sixth, the seventh and the eighth sub-dimensions $(\mathrm{p}<0.05)$. Tukey test was applied to reveal in favour of which group the significant difference occurred depending on key competencies. As it has been given in Table 7, significant differences were found among prospective mathematics teachers' scores depending on the type of high school they had graduated from. Tukey test indicated that these differences were available for seven sub-dimensions of the "Key Competencies for Lifelong Learning", except for the second sub-dimension-“Communicative Competence at a Foreign Language" $(\mathrm{p}<0.05)$.

As it comes to the first sub-dimension "Communicative Competence at Native Language", significant differences were found among the participants who had graduated from Anatolian High School and High School of Science, Vocational High School (infavour of Anatolian High School); among the participants who had graduated from Anatolian Teacher Training High School and High School of Science, Vocational High School School (infavour of Teacher Training High School); among the participants who had graduated from other high schools and Vocational High School (infavour of Other Schools, $\mathrm{p}<0.05$ ). 
For the third sub-dimension "Mathematical Basis Competence at Science and Technology", significant differences were found among the participants who had graduated from Anatolian High School and High School of Science, Vocational High School (infavour of Anatolian High School); among the participants who had graduated from Anatolian Teacher Training High School and High School of Science, Vocational High School (infavour of Teacher Training High School, $\mathrm{p}<0.05)$.

In the fourth sub-dimension "Digital Competence", significant differences were found among the participants who had graduated from Anatolian High School and High School of Science, Vocational High School (infavour of Anatolian High School); among the participants who had graduated from Anatolian Teacher Training High School and High School of Science, Vocational High School (infavour of Teacher Training High School, $\mathrm{p}<0.05)$.

The results related to the fifth sub-dimension "The Competence of Learning to Learn" indicated that significant differences were found among the participants who had graduated from Anatolian High School and High School of Science, Vocational High School (infavour of Anatolian High School); among the participants who had graduated from Anatolian Teacher Training High School and High School of Science, Vocational High School (infavour of Teacher Training High School, p<0.05).

In the way of the sixth sub-dimension "The Competence of Social Citizenship Awareness", significant differences were found among the participants who had graduated from Anatolian High School and High School of Science, Vocational High School (infavour of Anatolian High School); among the participants who had graduated from Anatolian Teacher Training High School and High School of Science, Vocational High School (infavour of Teacher Training High School); among the participants who had graduated from other high schools and Vocational High School (infavour of Other Schools, $\mathrm{p}<0.05$ ).

For the seventh sub-dimension "The Competence of Sense of Initiative and Entrepreneurship", significant differences were found among the participants who had graduated from Anatolian High School and High School of Science, Vocational High School (infavour of Anatolian High School); among the participants who had graduated from Anatolian Teacher Training High School and High School of Science, Vocational High School (infavour of Teacher Training High School); among the participants who had graduated 
Aykaç, Aslandă̆ E Köğce

from other high schools and Vocational High School, High School of Science (infavour of Other Schools, $\mathrm{p}<0.05)$.

The results regarding the eighth sub-dimension "The Competence of Cultural Awareness and Expression" showed that significant differences were found among the participants who had graduated from Anatolian High School and High School of Science, Vocational High School (infavour of Anatolian High School); among the participants who had graduated from Anatolian Teacher Training High School and High School of Science, Vocational High School(infavour of Teacher Training High School); among the participants who had graduated from other high schools and Vocational High School (infavour of Other Schools, $\mathrm{p}<0.05)$.

\section{Discussion and Conclusion}

Continuous change of knowledge and needs in today's society make it necessary to raise individuals who can use knowledge and skills effectively in daily life. This is possible with the training of teachers as competent individuals in terms of social and professional life. In other words, education faculties have an important role in raising teachers who are open to new ideas, who have developed lifelong learning skills in self-regulation and adaptation to changing conditions and to produce solutions to the problems encountered. In order to make it easier for these prospective teachers to acquire the necessary skills during their education, educational programs should be reorganized and developed in a way to improve their lifelong learning competencies (Murdoch-Eaton \& Whittle, 2012). The present study has revealed that the prospective mathematics teachers participated in the research have high level of life-long learning competencies, which has been a desired objective for future societies. Although the scores taken from the scale are high, providing undergraduates with numerous facilities or enhancing their habits and interests continuously are among the leading responsibilities of higher education institutions in the context of lifelong learning and sustainability. In parallel with the results of the study Karakuş (2013) found out that vocational school students' lifelong learning competencies are at a good level; Kılıç (2014) believes that prospective teachers' perceptions of lifelong learning are at a moderate level. She also revealed that prospective teachers care about lifelong learning and they believe that it is necessary and important to create educational opportunities in today's life conditions. Similarly, Selvi (2011) claimed that teachers can only develop students' lifelong learning 
skills when they improve themselves as lifelong learning individuals. On the other hand, Coşkun (2009) claimed that undergraduates have lower level of lifelong learning tendencies.

There are many researches on lifelong learning in literature in recent years (Aksoy, 2013; Akyol, Başaran \& Yeşilbaş, 2018; Coşkun, 2009; Coşkun, 2012; Demirel \& Yağcı, 2012; Gencel, 2013; Güleç, Çelik \& Demirhan, 2013; Kılıç, 2014; Oral \& Yazar, 2015; Poyraz \& Titrek, 2013; Samanc1 \& Ocakc1, 2017; Yaman \& Yazar, 2015). When the researches on this subject have been investigated, it has been seen that the relationship between lifelong learning and many factors has been examined. They have generally focuses on teachers' and students' lifelong learning trends, the relationship between lifelong learning and technologies, comparing international practices in lifelong learning and the practices in Turkey.

Universities play an important role for prospective teachers to prepare themselves for their profession and life as active individuals. For this reason, universities should raise their students in a way that they can cope with the problems they face in every area of life.The findings accessed in the present study provide support to the hypothesis gender is an important variable having a positive effect on lifelong learning competencies of prospective mathematics teachers. It appears that gender can be accepted as an effect on the lifelong learning competencies of participants. This finding signals the importance of multi facets of lifelong learning for both genders when searching the advantages of learning in various atmospheres. Similar to this finding of the study Coşkun (2012), Gencel (2013), Kılıç (2014) found out gender have a significant impact on lifelong learning competencies of prospective teachers in favour of female participants, which means that male prospective teachers need help in taking increased responsibility for their own lifelong learning competencies. Contrary to this finding of the present study, studies conducted by Oral and Yazar (2015), Şahin, Akbaşlı and Yanpar (2010), Yaman and Yazar (2015) and Yılmaz (2016) determined that lifelong learning tendencies of prospective teachers did not differ significantly according to their gender.

This study revealed that professional experience of mathematics teachers had a significant impact on lifelong learning competencies. Similarly, Scheuch (2007) emphasized in his research that universities may lead the path of their students when they have an atmosphere encouraging research and creativity. In her study it was stated that the effects of classification (seniors versus juniors) are evident in the increased likelihood of overall 
participation of seniors and the types of activities in which they participated. She also claimed that students studying in the upper classes participated in research activities more than the students in lower grades. Coşkun (2009) found out no significant difference among the lifelong learning tendencies of undergraduates depending on their grades. It is not surprising that there was no significant difference between prospective mathematics teachers' lifelong learning competencies, since lifelong learning consists of different competence areas. By considering a broader notion it can be accepted that the grades of undergraduates may have an important effect on their lifelong learning competencies, as university life should have responsibilities to enhance their students' lifelong learning competencies. According to Dunlap (2003), students' participation in lifelong learning is as important as learning lifelong learning skills.

An important finding of the study was that prospective mathematics teachers' lifelong learning competencies differed depending on the high school they graduated from. When the sub-dimensions are examined in a detailed way, it can be seen that in seven subdimension of the "Key Competencies for Lifelong Learning Scale" different type of high school students had higher scores, which means that the type of the high school the participant graduated from can be accepted to have a meaningful impact. With this in mind, colleges and universities may wish to evaluate their undergraduate population to obtain a sense of student typologies that influence undergraduates' lifelong learning competencies. This may also be consistent with the results of study by Scheuch (2007) claiming that social science students appeared to be more likely to participate in research and creative activities. As Baumann (2006) highlighted that higher education institutions have roles as a part of a "liquid life". Recently, such institutions are social and extrovert in nature. In addition, lifelong learning proficiency scores of prospective mathematics teachers who graduated from Anatolian and teacher training high schools are higher than those of prospective mathematics teachers who graduated from other high school types. As such, it can be inferred that as the students were registered to these high schools depending on their exam results, they might have more awareness of lifelong learning. Accordingly, life-learning competencies are vitally important for all educational institutions.

The results obtained from the research can be summarized as following:

The prospective mathematics teachers participated in the research have high level of life-long learning competencies. 
Aykaç, Aslandă̆ \& Köğce

It was found out that lifelong learning competency scores of prospective mathematics teachers showed a significant difference according to their gender in favor of female prospective teachers.

It was revealed that lifelong learning proficiency scores of prospective mathematics teachers did not show a significant difference according to their grade levels.

It was revealed that lifelong learning proficiency scores of prospective mathematics teachers showed a significant difference according to the high school types they graduated from.

There were also found significant differences among the sub-dimension scores of prospective mathematics teachers depending the high schools they graduate from.

The findings of the research revealed that experimental research is needed that examine the different dimensions of lifelong learning competencies. Continuity of learning related to lifelong learning can be achieved by conducting such research. Research can be undergone with students from different departments can so as to get a hold of an overview on students' lifelong learning competencies. With respect to the consequences of the present study, it can be recommended that both formal, informal and non-formal activities at universities adopted by students are vital dynamics for developing lifelong learning competencies to contribute to the sustainable development.

\section{Acknowledgement}

In this study, all the rules specified in the "Higher Education Institutions Scientific Research and Publication Ethics Directive" were followed. None of the actions specified under the second section of the Directive, "Scientific Research and Publication Ethics Actions" have been carried out.

Ethics Committee Permit Information

Name of the board that carries out ethical evaluation: Niğde Ömer Halisdemir University

The date of the ethical assessment decision: 01/04/2020

Ethical assessment document number number: 2020/03-12

Authorship Contribution Statement

Murtaza AYKAÇ: Conceptualization, design of the work, literature search, data analysis, data interpretation, writing - review and editing.

Buket ASLANDAĞ: Conceptualization, data collection, preliminary analyses, manuscript draft, writing, manuscript revision

Davut KÖĞCE: Conceptualization, design of the work, literature search, data analysis, data interpretation, writing - review and editing. 


\section{References}

Akbaş, O. \& Özdemir, S. M. (2002). Lifelong learning in the european union. Journal National Education, (156), 112- 126.

Aksoy, M. (2013). Lifelong learning as a concept and european union of lifelong learning adventure. Bilig, 64, 23- 48.

Akyol, B., Başaran, R. \& Yeşilbaş, Y. (2018). Life satisfaction level and lifelong learning tendencies of public education center trainees. Mehmet Akif Ersoy University Journal of Faculty of Education, 48, 301-324

Bağ c1, E. (2011). Lifelong education policies in turkey in the process of evropean union membership. Ondokuz Mayıs University Journal of Faculty of Education, 30(2), 139-173.

Bauman, Z. (2006). Liquid life. Cambridge: Polity

Çepni, S. (2018). Introduction to research and project studies. Ankara: Pegem Academy.

Coşkun, Y. D. (2009). Investigation of lifelong learning tendency of undergraduate students? In terms of some variables. Unpublished doctoral thesis, Hacettepe Universitesity Social Sciences Institute, Ankara.

Coşkun, Y. D. \& Demirel, M. (2012). Lifelong learning tendencies of üniversity students. Hacettepe University Journal of Education, 42, 108-120.

Demirel, M. \& Yağcl, E. (2012). Perceptions of primary school teacher candidates about lifelong learning, Hacettepe University Journal of Education, 1, 100-111.

Dunlap, J. C. (2003). Preparing students for lifelong learning: a review of instructional features and teaching methodologies. Performance Improvement Quarterly, 16(2), 6-25

Gencel, İ. E. (2013). Prospective teachers' perceptions towards lifelong learning competencies. Education and Science, 38(170), 237-252.

Güleç, İ., Çelik, S. \& Demirhan, B. (2013). What is lifelong learning? An evaluation on definition and scope. Sakarya University Journal of Education, 2(3), 34-48.

Gür, E. (2014). Factors effecting lifelong learning inclinations of prospective teachers (Doctorate Thesis). Department of Curriculum and Instruction Abant İzzet Baysal University.

Karakuş, C. (2013). Lifelong learning competences of vocational school students. Journal of Research in Education and Teaching, 2 (3), 26-35.

Kılıç, Ç. (2014). Pre-service teachers' perceptions towards lifelong learning. Journal of Research in Education and Teaching, 3(4), 79-87.

Ministry of National Education (MoNE) (2014). Turkey lifelong learning strategy document for 2014-2018. http://abdigm.meb.gov.tr/projeler/ois/013.pdf

Murdoch-Eaton, D. \& Whittle, S. (2012). Generic skills in medical education: developing the tools for successful lifelong learning. Medical Education, 46(1), 120-128.

Oral, B. \& Yazar, T. (2015). Examining the perception of prospective teachers about life-long learning in terms of various variables. Electronic Journal of Social Sciences, 14(52), 1-11.

Poyraz, H. \& Titrek, O. (2013). Development of lifelong learning in Turkey. Abant Izzet Baysal University. Journal of Faculty of Education, 13(1), 115-131. 
Aykaç, Aslandă̆ \& Köğce

Samanc1, O. \& Ocakc1, E. (2017). Lifelong learning. Bayburt Journal of Faculty of Education, 12(24), 711-722.

Scheuch, K. L. (2007). Faculty research orientation, undergraduate research activities and student outcomes. Unpublished doctoral dissertation, Florida State University, Florida.

Selvi, K. (2011). Teachers' lifelong learning competencies. IJOCIS, 1(1), 61-69.

Şahin, M., Akbaşl1, S. \& Yanpar, T.Y. (2010). Key competences for lifelong learning: the case of prospective teachers. Educational Research and Review, 5(10), 545-556.

Şahin, Ç. \& Arcagök, S. (2014). Examination of the teachers' lifelong learning competences levels in terms of some variables. Adryaman University Journal of Social Sciences, 7(16).394-417.

The World Bank. (2003). Lifelong learning in the global knowledge economy: Challenges for developing countries. A World Bank Report, The World Bank, Washington, D.C.

Yaman, F. \& Yazar, T. (2015). Investigating of lifelong learning tendency of teachers (The example of Diyarbakır). Kastamonu University Kastamonu Education Journal, 23(4), 1553-1566.

Yıldız-Durak, H. \& Şahin, Z. (2018). Investigation of the contribution of coding training in teaching candidates to the development of lifelong learning competencies. Journal of Ege Education Technologies, 2(2), 55-67.

Yilmaz, M. (2016). Examination of teachers' lifelong learning tendencies. Mustafa Kemal University Journal of Social Sciences Institute, 13(35), 253-262. 